\title{
SOCIAL MEDIA AND HIGHER EDUCATION INSTITUTIONS: USING SOCIAL NETWORKS TO RECRUIT STUDENTS
}

\section{Tetiana Datsenko}

ORCID iD 0000-0001-5494-9834

PhD (Psychology), Head of PR

Borys Grinchenko Kyiv University

13-b Marshala Tymoshenka Str., 04212 Kyiv, Ukraine

t.datsenko@kubg.edu.ua

\section{Olha Vyhovska}

ORCID iD 0000-0002-8635-9991

$\mathrm{PhD}$ (Political Sciences),

Head of Scientific-Research Laboratory

of Internationalization of Higher Education

Borys Grinchenko Kyiv University

18/2 Bulvarno-Kudriavska Str., 04053 Kyiv, Ukraine

o.vyhovska@kubg.edu.ua

\section{Andrii Sinko}

ORCID iD 0000-0001-7179-8118

Master Student, Specialist of PR

Borys Grinchenko Kyiv University

13-b Marshala Tymoshenka Str., 04212 Kyiv, Ukraine

a.sinko@kubg.edu.ua

https://doi.org/10.28925/2518-7635.2020.5.9

\section{ABSTRACT}

The number of offers in higher education both in Ukraine and everywhere in the world is quite large, and accordingly the competition for new students is high. Higher education institutions (HEIs) in such conditions must know how to effectively present themselves to target audiences. New digital technologies and social media can help. Social media has become especially important during the quarantine restrictions associated with the COVID-19 pandemic. Universities have to use the Internet as their main source of communication, both for disseminating information and for recruiting new students. As a result, the use of social media in higher education is growing rapidly, and HEIs are making increasing efforts to establish their online presence. Higher education institutions try to establish contact with their potential students when they study in high school using various media platforms, including social networks and messengers. 
This article is devoted to the theoretical analysis and practical research of using social media, in particular social networks, by higher education institutions in Ukraine to recruit students and maintain two-way communication with them. The study has shown that most freshmen actively used social networks to search for information about a HEI and some of them maintained a dialogue with the university through these social networks before the admission. An important regularity has been defined: the more widely and qualitatively a higher education institution is presented in social networks, the more often entrants and students turn to them in search of the necessary information. However, social networks still remain an auxiliary tool, as the majority of Ukrainian entrants first of all trust the official websites and feedback of graduates when choosing a higher education institution. In any case, the higher education marketing is becoming increasingly digital and this trend doesn't look to slow down anytime soon.

Key words: higher education institution (HEI), higher education marketing (HEM), social media, social networks, student recruitment.

(C) Tetiana Datsenko, Olha Vyhovska, Andrii Sinko, 2020

\section{INTRODUCTION}

Nowadays, higher education institutions have to operate in a competitive environment. On the one hand, it is due to the growing demand for highly qualified personnel capable to work effectively in the context of social transformations towards innovative technologies, on the other hand - a large number of proposals in the field of educational services (public, municipal, private institutions, etc.). The vast majority of universities in Ukraine are funded from the state or local budgets. However, such funding is also provided on a competitive basis, on the principles of openness and transparency, equality, objective and impartial evaluation of bids (On Higher Education, 2014).

Universities around the world compete with each other in recruiting students, top researchers and funding, and only those that remain relevant and take advantage of new digital technologies will benefit at this digital age (PwC, 2015).

Uncertainty and limited ability to measure the success indicators of the social media use have historically deterred HEIs from using social networks to recruit students. However, increasing competition and students' and parents' concerns that the university is not worth the investment, are factors that have pushed HEIs to move forward into the unknown (Pew Research Center, 2011).

According to the Digital 2020 report of the resource DataReportal, in Ukraine there are 27.46 million Internet users, which is 63\% of the population. Among them 19.00 million (43\%) are active users of social networks. The number of social network users is growing rapidly, as evidenced by an increase of 1.5 million (+8.3\%) in the period from April 2019 to January 2020 (DataReportal, 2020). 
It can be assumed that during the COVID-19 pandemic and strict quarantine restrictions, in particular restrictions on movement, the number of active Internet users increased significantly. The pandemic has actually made online marketing the main tool for attracting new students in 2020. Professionals involved in student recruitment and marketing have to use social media as one of the main sources of communication, both for the dissemination of information and for the direct attraction of students. As a result, the use of social media in higher education is growing rapidly, and HEIs are making every effort to maintain their online presence.

Therefore, the use of social media to maintain a positive image of a HEI among potential students and the general public is no longer a whim of certain universities, but a present-day requirement, an adequate response to the challenges of modern realities. This raises the questions: "What are the benefits of social media to the modern university in solving this problem?", "How effective are social media for HEM?", "What social networks to use?"

\section{BACKGROUND}

The research has raised the issue of the functioning of higher education institutions in the competitive global environment and the search for new forms of student recruitment, including social media (Choudaha \& Chang, 2012). The term "social media", which describes a wide range of nextgeneration Internet applications, has aroused considerable commercial interest and discussion in scientific circles. Among the topics in these discussions are: 1) the impact of social media on human behavior (Barker, 2009; Kolbitsch \& Maurer, 2006); 2) their role in the enrollment of students by universities and in the process of HEI selecting by students (Constantinides \& Zinck Stagno, 2012; Khan, 2013; Kusumawati, 2019; Martin, 2015).

Social Media is defined as: "forms of electronic communication (as websites for social networking and microblogging) through which users create online communities to share information, ideas, personal messages, and other content (as videos)" (Martin, 2015: pp. 11-12). Social media is typically used for social interaction, access to information and decision making. The research by U.S. scientists shows that people who use social media for personal communication are more likely to use services such as Facebook, Instagram, Twitter and YouTube as a source for news and information, live conversations and entertainment. Users rely on these sources to keep in touch with family and friends, gather information and share what is important to them (Duggan et al., 2015; Lenhart et al., 2015; Martin, 2015).

In today's world, news and information spread faster than ever before. Social media has made it possible and it has offered unprecedented personalized and real-time access for people to connect with individuals and businesses in various ways, at any time of the day, even at night. Higher education 
is a competitive business in the large scale market. And without enrollment growth, higher education institutions will not sustain. Universities face the challenge of maintaining relevance among students who are increasingly more reliant on technology as a communication source. Social media is an everyday part of teens' lives and social spaces are effective places for universities to reach prospective students (Kusumawati, 2019; Martin, 2015).

Researchers Asatryan and Oh (2008) explained the affinity towards feedback from a Psychological Ownership Theory perspective using the example of the hospitality industry. Consumers tend to grow an affinity towards the organizations they receive service from and take ownership of the feedback that they leave on their websites. This observation shows justification why social media users might be inclined to actively spread by word of mouth, their experiences about an education institution if suitable platforms are provided. Apparently, this is where one of the greatest possibilities for universities exists in gaining a long term intangible asset through the branding process from their consumers, the students (Khan, 2013).

Thus, the emergence of social media has made it possible to solve higher education marketing (HEM) tasks using the following innovations: 1) interactive presentation of the university (general information, mission, values, training areas, demonstration of environment and infrastructure, benefits, prospects, potential, etc.); 2) interactive communication online; 3) online PR (communication with media representatives, other organizations); 4) the activities of virtual pages and communities in social networks (Facebook, Twitter, LinkedIn, Instagram, Pinterest, etc.); 5) banner advertising; 6) exchange of services via the Internet (distribution of news, offers, etc.); 7) interactive surveys (of employees, students, graduates, potential applicants and their parents); 8) operational marketing research on the Internet (demand, needs and behavior of consumers, the effectiveness of banner advertising, traffic to sites, pages, etc.) (Datsenko, 2016).

\section{METHODOLOGY}

The research was based on the well-known scientific ideas that social media is: 1) an important channel of communication between HEIs and target audiences; 2 ) an effective tool for attracting new students. However, along with the rapid development of technology and new challenges in higher education, it is necessary to study promptly the known phenomena in a new environment.

The study consisted of three stages. The first stage was preparatory, devoted to the analysis of scientific sources and the development of a questionnaire; at the second stage, with the help of the Internet, the survey was conducted; the third stage included processing and analysis of the received data.

The study was conducted by means of an indirect Internet survey. The custom questionnaire was developed for this survey. The questionnaire included 16 items, among which there were 13 closed- and 3 open-ended 
questions. The survey involved 735 respondents $(n=735)$ who entered HEI this year and lived in Ukraine.

The survey was open from 18 to 23 September 2020. It was conducted in the Ukrainian language.

\section{MAIN RESULTS}

Students from 5 cities of Ukraine - Kyiv, Kryvyi Rih, Lviv, Uman and Vinnytsia took part in the research. Such a fairly wide geographical coverage and speed of data collection became possible owing to the Internet. The age of respondents: $17-18$ years old $-88 \%$, over 18 years old $-12 \%$.

The majority of respondents $(\mathbf{4 5 . 6} \%)$ answered that they learned about their HEI from the Internet, slightly less $(\mathbf{4 3 . 3} \%)$ - from acquaintances and a small part $(\mathbf{1 1 . 2} \%)$ - from family members (Figure 1$)$.

\section{How the students learned about \\ their HEI \% $(n=735)$}

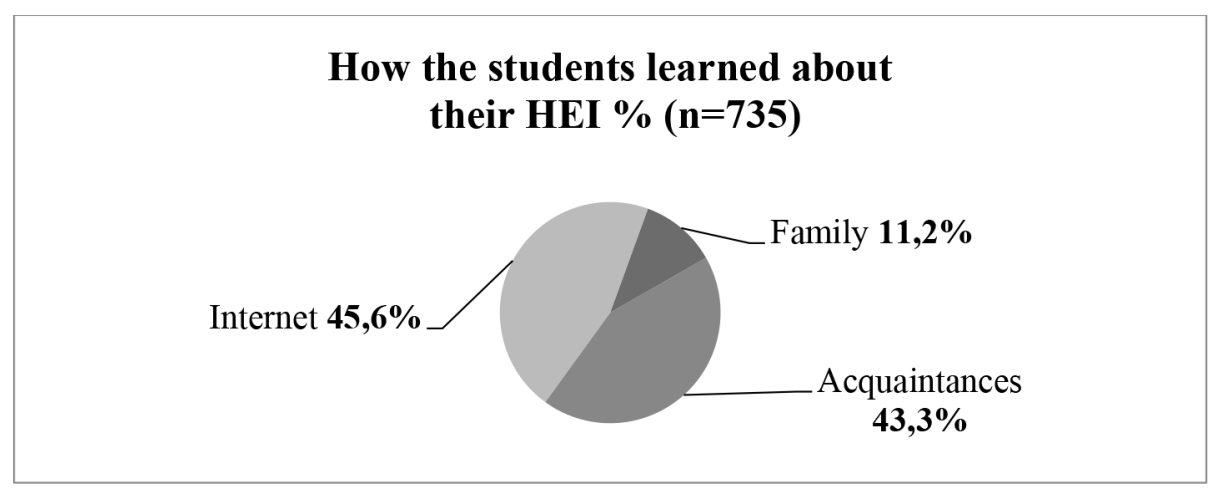

Figure 1. The main sources of information about HEI (according to respondents)

It is important that $\mathbf{4 1 . 9 \%}$ of respondents paid attention to online comments when choosing HEI. When asked on what resources students searched for information about HEI - $\mathbf{6 4 . 9} \%$ answered that they did it on the main website of the institution, $\mathbf{2 9 . 3} \%$ - on the official pages of social networks, the remaining $5.9 \%$ - on other educational websites and portals (Figure 2).

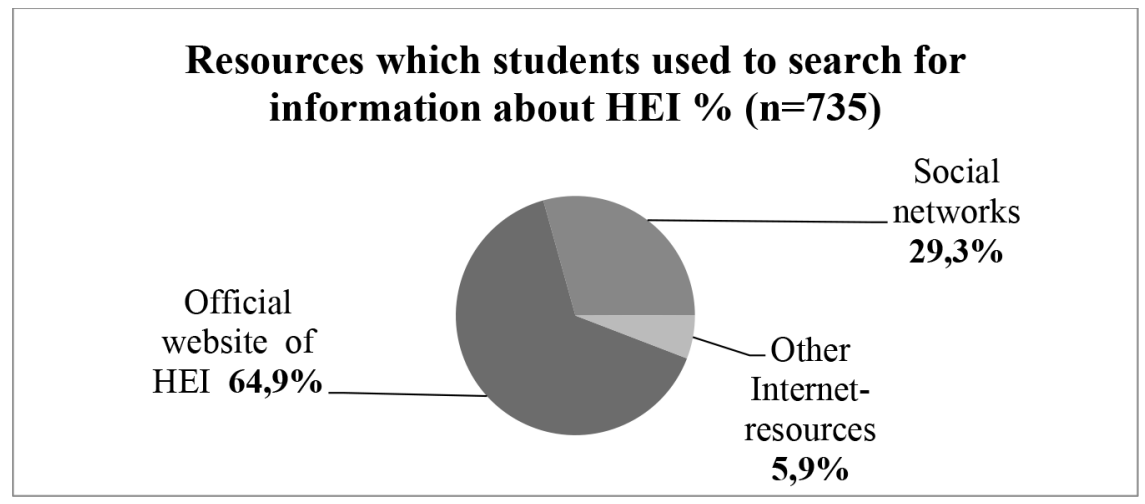

Figure 2. The main Internet resources for searching information about HEI (according to respondents) 
As we can see, social networks have a significant share of trust. It is important to note that the entrants' choice of social networks as the main source of information about the university also depends on the representation of the institution in social networks.

The results with regard to which social media students use to find out about news and events in their HEI turned out to be interesting. Thus, the vast majority - 77.4 \% indicated they used Instagram, $5.7 \%-$ Facebook, $4.5 \%$ - YouTube. Other popular social media were mentioned by $2 \%$ or less of respondents. In addition, $\mathbf{2 3 . 9} \%$ of respondents said that they maintained a dialogue with the representatives of HEI before admission through social networks.

As for what the content and design of the pages of an educational institution in social networks should be, the students emphasized that in the first place there should be high quality information (75.6\%), aesthetically attractive (18.6\%), but the level of audience involvement turned out to be less important (5.7\%) (Figure 3).

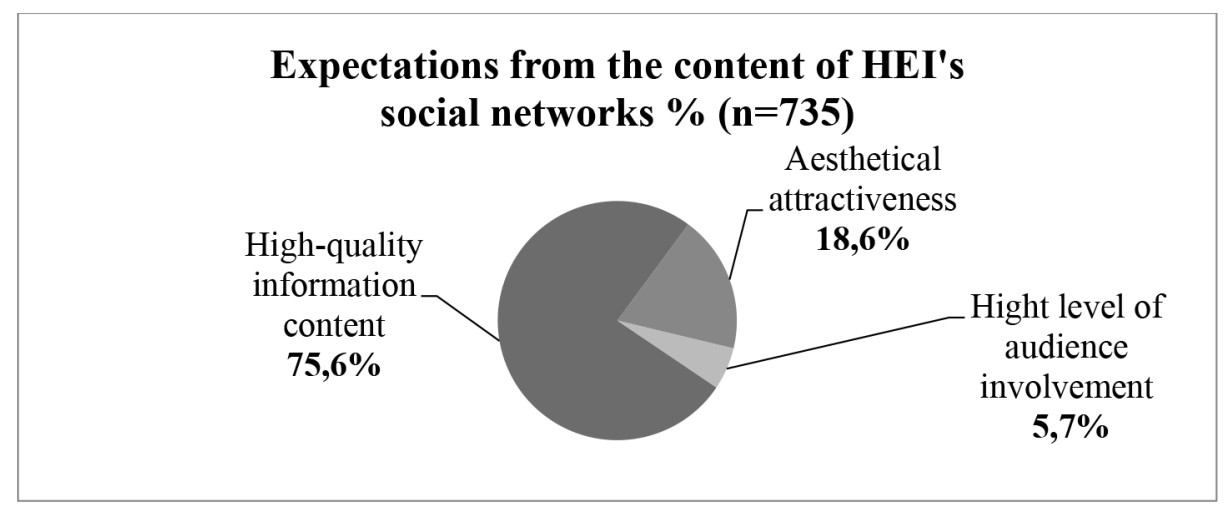

Figure 3. Expectations from the HEI's pages content in social networks (according to respondents)

As the research shows, information about the institution's reputation, prospects, educational programs, logistics and academic staff has proved to be of the most relevance to students. Entertainment content and audience engagement have been less important. Most students noted the convenience and efficiency of such communication channel as social networks.

\section{CONCLUSIONS}

Thus, the conducted research enables us to draw the following conclusions: 1) the Internet is the main source for searching information about higher education institutions for prospective students; 2) most entrants trust the official websites of HEI and students comments; 3 ) social networks are an important resource for recruiting students and maintaining communication between potential students, students and HEI representatives; 4) the better and more qualitatively a HEI is represented in social media, the more effective they are. 
Digital technologies are nearby and they are here to stay. Mobile devices are always and everywhere switched on; social media is the main channel of communication for many; new capabilities of cloud computing provide a means for creating new tools and products at a speed that was previously difficult to imagine; geolocation sensors enable new tracking and targeting capabilities; digital is now the first choice for media consumption - the list goes on, according to $\mathrm{PwC}$ (2015). Such progress affects and changes higher education and science, and it will gain momentum.

The young audience is using all new tools and applications that are appearing and developing at an extremely fast pace, and the most agile universities are trying to keep up. As the competition among higher education institutions to attract the best students continues to grow, both in Ukraine and world-wide, universities have to demonstrate that they are capable of providing the digital experience that students nowadays take for granted. In digital era, where the voice of consumers is more prevalent than ever, transforming students into ambassadors for their university is one of the most powerful marketing tools available.

The universities that are aware of the power of social media and positive impact they can have on student recruitment will always be ahead. The universities with a large presence in social networks are able to maintain a reliable two-way connection with their target audiences - to present scientific achievements, share information, news, explanations, answer questions quickly and efficiently.

The strategies for maintaining social networks will look different for each institution, depending on its specifics and goals. Removing barriers and enabling certain university departments to create their own social media pages can help revitalize and strengthen the university-wide online presence.

\section{REFERENCES}

Asatryan, V., \& Oh, H. (2008). Psychological ownership theory: An exploratory application in the restaurant industry. Journal of Hospitality \& Tourism Research, 32(3), 363. DOI: https://doi.org/10.1177/1096348008317391.

Barker, V. (2009). Older Adolescents' Motivations for Social Network Site Use: The Influence of Gender, Group Identity, and Collective Self-Esteem. Cyberpsychology \& behavior: the impact of the Internet, multimedia and virtual reality on behavior and society. 12. 209-13. DOI: https://doi. org/10.1089/cpb.2008.0228.

Choudaha, R., \& Chang, L. (2012). Trends in International Student Mobility. URL http://www.wes.org/ewenr/12feb/feature.htm

Constantinides, E., \& Zinck Stagno, M. (2012). Higher Education Marketing: A Study on the Impact of Social Media on Study Selection and University Choice. International journal of technology and education marketing, 2(1), 41-58. DOI: https://doi.org/10.4018/ijtem.2012010104. 
DataReportal (2020, February 18). “Digital 2020: Ukraine”, DataReportal. URL: https://datareportal.com/reports/digital-2020-ukraine

Datsenko, T. (2016, September 29-30). Supporting Positive Image of Modern University by Interactive Media. (in Ukrainian). Zbiór raportów naukowych. Konferencji Miedzynarodowej Naukowo-Praktycznej "Economy. Zarzadzanie. Osiągnięcia naukowe, rozwój, propozycje”(pp. 12-14.).

Duggan, M., Lenhart, A., Lampe, C., \& Ellison, N. (2015). Parents \& Social Media. Pew Research Center - Internet, Science \& Tech. http://www. pewinternet.org/2015/07/16/parents-and-social-media.

Khan, R. (2013). Marketing Education Online: A Case study of New Zealand Higher Education Institutions. Procedia - Social and Behavioral Sciences. 103. 637-646. DOI: https://doi.org/10.1016/j.sbspro.2013.10.382.

Kolbitsch, J., \& Maurer, H. (2006). The transformation of the web: How emerging communities shape the information we consume. Journal of Universal Computer Science, 12, $187-213$. [Web of Science ${ }^{\circledR}$ ].

Kusumawati, A. (2019). Impact of Digital Marketing on Student DecisionMaking Process of Higher Education Institution: A Case of Indonesia. Journal of e-Learning and Higher Education. 1-11. DOI: https://doi. org/10.5171/2019.267057.

Lenhart, A., Smith, A., Anderson, M., Duggan, M., Perrin, A. (2015). “Teens, Technology and Friendships." Pew Research Center. URL: http://www. pewinternet.org/2015/08/06/teens-technology-and-friendships/

Martin, C. (2015). "Social Media Engagement and Collegiate Recruitment: An Examination of the Use of Social Networks in the College Recruitment and Student Choice Processes". URL: http://digitalcommons.wku.edu/diss/93.

On Higher Education \# 1556-VII. (2014). URL: https://zakon.rada.gov.ua/ laws/show/en/1556-18/ed20140701\#Text

Pew Research Center (2011). Is college worth it? College presidents, public access, value, quality and mission of higher education. URL: http://www. pewsocialtrends.org/2011/05/15/is-college-worth-it/.

PwC (2015). "The 2018 digital university: Staying relevant in the digital age," $P w C$. URL: https://www.pwc.co.uk/assets/pdf/the-2018-digital-universitystaying-relevant-in-the-digital-age.pdf

\section{СОЦІАЛЬНІ МЕДІА ТА ЗАКЛАДИ ВИЩОЇ ОСВІТИ: ВИКОРИ- СТАННЯ СОЦІАЛЬНИХ МЕРЕЖ ДЛЯ РЕКРУТИНГУ СТУДЕНТІВ}

Даценко Тетяна, кандидат психологічних наук, завідувач НМЦ інформаційно-рекламної та профорієнтаційної діяльності, Київський університет імені Бориса Грінченка, вул. Маршала Тимошенка, 13-6, 04212 Київ, Україна, t.datsenko@kubg.edu.ua 
Виговська Ольга, кандидат політичних наук, завідувач НДЛ інтернаціоналізації вищої освіти, Київський університет імені Бориса Грінченка, вул. Бульварно-Кудрявська, 18/2, 04053 Київ, Україна, o.vyhovska@kubg.edu.ua

Сінько Андрій, магістрант, фахівець зі зв’язків з громадськістю та пресою, НМЦ інформаційно-рекламної та профорієнтаційної діяльності, Київський університет імені Бориса Грінченка, вул. Маршала Тимошенка, 13-б, 04212 Київ, Україна, a.sinko@kubg.edu.ua

Кількість пропозицій у вищій освіті, як в Україні, так і у світі в иілому, достатньо велика, а відповідно і конкуренція за нових студентів. Заклади вищої освіти (ЗВО) в таких умовах повинні знати як ебективно презентувати себе цільовим аудиторіям. У цьвому можуть допомогти нові иифрові технології та соціальні медіа. Особливо важливими соціальні медіа стали у період карантинних обмежень, пов'язаних із пандемією COVID-19. Університети змушені використовувати Інтернет як основне джерело комунікацї, як для розповсюдження інбормаціі, так і для безпосереднього набору студентів. Як результат, використання соціальних медіа у галузі вищьоі освіти стрімко зростає і ЗВО докладають усе більше зусиль щодо своєї присутності в Інтернет-просторі. Заклади вищої освіти намагаються налагодити контакт із потенційними абітурієнтами ще в стариих класах школи, використовуючи різні медіаплатформи, а саме соиіальні мережі та месенджери.

Ця стаття присвячена теоретичному аналізу та практичному дослідженню проблеми використання соціальних медіа, зокрема соціальних мереж, закладами вищої освіти в Украйні для рекрутингу студентів та підтримки двостороннього зв'язку з ними. Дослідження показало, щзо більшість першокурсників активно використовували соиіальні мережі для пошуку інформацї про 3ВО, частина з них підтримувала діалог із університетом за допомогою соиіальних мереж до вступу. Важливою $є$ закономірність: чим ширше та якісніше $3 B О$ представлений у соціальних мережах, тим частіше абітурієнти та студенти звертаються до них за пошуком необхідної інбормаціі. Проте сочіальні мережі все ж залишаються допомінним інструментом, адже більшість українських абітурієнтів при виборі 3ВО, у першу чергу, довіряють обічійним вебсайтам та відгукам випускників. У будь-якому випадку, маркетинг вищої освіти стає все більш иифровим, $і$ ия тендениія найближчи часом не зменuиться.

Ключові слова: заклад вищої освіти (ЗВО), маркетинг вищої освіти, соціальні медіа, соціальні мережі, рекрутинг студентів. 